\section{Research Article}

(C) 2022 Phatanasakoo.

This is an open access article licensed under the Creative Commons Attribution-NonCommercial 4.o International License

(https://creativecommons.org/licenses/by-nc/4.o/)

\title{
Rajabhat University Development Model for Becoming an Entrepreneurial University
}

\author{
Ajchareeya Phatanasakoo* \\ Watcharin Sutthisai \\ Sitthiporn Soonthorn \\ Doctor of Public Administration \\ Program in Public and Private Management, \\ Rajabhat Mahasarakham University, \\ Mahasarakham, Thailand \\ *Corresponding Author
}

DOI: https://doi.org/10.36941/ajis-2022-0052

\begin{abstract}
This research aimed (1) to study the level of development factors of Rajabhat Universities in the northeastern region affecting an entrepreneurial university; (2) to study the level of characteristics of entrepreneurial universities in the Northeastern region; (3) to study the factors of development of Rajabhat University in the Northeastern region that affect to being an entrepreneurial university; and (4) to propose a model for the development of Rajabhat University in the northeastern region into an entrepreneurial university. The population of the study was the administrators and personnel of the Rajabhat University of Thailand. The sample size of the study was three hundred and sixty respondents. The statistical analysis of the research was done using descriptive analysis and multiple regression analyses. The results showed that (1) the mean values of development factors variable and characteristics of an entrepreneurial university were high; (2) development factors that influenced the characteristics of an entrepreneurial university were organizational strategy and structure, system, shared value, politics and policies, economics, and environment; and (3) when arranging the importance of development factors that clearly affected the university, it was found that organizational strategy was the most important, followed by shared values, systems, and organizational politics and policies. This study suggests that the administrators of Rajabhat Universities of Thailand should focus on the development factors that are of high importance such as corporate strategy, shared values, politics, and organizational policies. This will eventually lead to a successful development towards an entrepreneurial university in the future.
\end{abstract}

Keywords: Development Model, Rajabhat University, Entrepreneurial University, Thailand

\section{Introduction}

The world is constantly changing. Changing the world in all aspects affects the adaptation of populations and organizations. The technological changes in the world are so obvious and remarkable that people in all areas have to adapt greatly. Politics and economies of all countries have 
clearly adapted to cope with technological changes and innovations. Governments must change themselves to be able to run the country well and support their people to adapt to the changes of the world as well as to connect with the governments of other countries in global and regional administration so that it moves together and is consistent with every country in the world. In the education sector of the country, it is necessary to adapt to the trends of such global changes so that the education system is consistent with the changes and suitable for the changing social environment. The Thai government attaches great importance to the national education system at all levels. The government has always supported education in order to create citizens of the country to have the knowledge and skills to have the right career according to their needs and lead to the development of the country in all aspects. Universities around the world are under pressure to increase their capacity for modern economic and commercial responsiveness. Therefore, it is not enough for universities to play a single role in education and research, but modern universities must also be a source of innovation (Alves, Fischer, Schaeffer, \& Queiroz, 2018; Audretsch, 2014; Bell; 2011; Dabic, 2021; Guerrero, Toledano, \& Urbano, 2011). Rajabhat Universities are one of the important mechanisms to support such government policy. Rajabhat Universities throughout Thailand have strategies to develop areas where universities are responsible. The group of Thai Rajabhat Universities has a mission to develop people and communities in responsible areas to create a knowledgeable, skilled and cultural society. In addition, Rajabhat University also has a mission to create a community with economic development, create jobs in the area, and maintain good cultural traditions of communities throughout Thailand. Therefore, the Thai government aims to support Rajabhat University as the center of area development in each region of Thailand by supporting it as a model university in the area. One approach that is currently interesting is the development of an entrepreneurial university. Entrepreneurship is characterized by innovation and proactive development. Entrepreneurial universities therefore work on a development model based on innovation, technology, and proactive work in the area. This approach will contribute to the creation of high-quality citizens of a country that is resilient to future global changes. And high-quality citizens will ultimately lead to the creation of a nation that develops and grows sustainably. Therefore, the researcher is interested in studying the development factors that affect the creation of Rajabhat University to be an entrepreneurial university. The benefits of this study will be for the group of Rajabhat Universities in Thailand, where the research results will be used as a guideline for the development of universities to accommodate future global changes and support the approach of the Thai government to develop the country towards sustainable growth.

\section{Research Objective}

This research aims to study the development of an entrepreneurial university in Thailand with an emphasis on Rajabhat Universities. The main objective of this research is to study the influence of various development factors on the establishment of an entrepreneurial university.

\section{Literature Review}

\subsection{Entrepreneurial orientation}

Entrepreneurship is a fundamental factor in the economy of all countries around the world (Cardella, Hernandez-Sanchez, \& Sanchez-Garcia, 2019; Guerrero, Toledano, \& Urbano, 2011). Entrepreneurship involves risk-taking, ambiguity tolerance, and innovation (Guerrero, Rialp, \& Urbano, 2008). The study of Popowska (2020) indicated that corporate entrepreneurship was the action necessary to develop creativity and innovation in an organization. Corporate entrepreneurship strikes a balance between leveraging existing knowledge with the challenge of creating and developing new knowledge in order to formulate organizational strategies in response to Continuous change of the corporate environment (Lassen, 2007). It has been found that many factors affect corporate entrepreneurship, 
such as the structure of the organization. organizational leadership, organizational networks, and external environmental factors (Sakhdari, 2016). Organizations that aim to be corporate entrepreneurship must develop personnel in the organization to have innovative thinking and behaviors (Tseng \& Tseng, 2019). Therefore, entrepreneurship and innovation are critical factors for the economic growth and competitiveness of organizations in the region (Elia, Secundo, \& Passiante, 2017). Entrepreneurship takes place in an entrepreneurial ecosystem with a focus on entrepreneurship in the subsets that develop entrepreneurial behaviors to make new things happen in the system (Fredin \& Liden, 2020). The entrepreneurial skills and motivations of individuals influence future entrepreneurial intentions, which will lead to risk-taking and commercial innovation (Ward, Hernandez-Sanchez, \& Sanchez-Garcia, 2019). Having a good role model will affect the development of entrepreneurial skills (Cardella, Hernandez-Sanchez, \& Sanchez-Garcia, 2019). Entrepreneurship must exhibit adaptive behavior and must cooperate with other sectors in a complex networked system (Fredin \& Liden, 2020). Social entrepreneurship will develop social innovations that result in better people's well-being, thus creating an entrepreneurial society (Thomas \& Pugh, 2020). An entrepreneurial society will have entrepreneurial traits that are the driving force behind the economic growth of the society and the country (Audretsch, 2014). Knowledge and knowledge management are critical factors in today's society (Dabic, 2012). Creating new knowledge is beneficial to innovation, competitiveness, and economic growth (Audretsch, 2014). The rise of innovation requires leadership that begins with the entrepreneurial way of the leader and this entrepreneurship can be passed on or taught to others (Bell, 2011; Gibb, 2012). In addition, the creation of innovation in the organization is necessary to create an organizational atmosphere that is ready for the expected innovation development, such as creating an innovation culture, designing an organizational structure that is suitable for innovation development (Gibb, 2012). Entrepreneurship is one of the key directions for the country's development and is also the direction of development towards an entrepreneurial university (Alves, Fischer, Schaeffer, \& Queiroz, 2018). Therefore, universities are increasingly playing an important role in the development of entrepreneurship and innovation (Margaca, Hernandez-Sanchez, Sanchez-Garcia, \& Cardella, 2021). This will affect the creation of new entrepreneurs for the society and economic development of the country (Thomas \& Pugh, 2020).

\subsection{Entrepreneurial University}

Universities are important to the national economy on the basis of knowledge by being an institution that creates value with knowledge for economic and social development (Audretsch, 2014; Guerrero, Toledano, \& Urbano, 2011; Guerrero, Urbano, \& Salamzadeh, 2014; Lehmann, Meoli, Paleari, \& Stockinger, 2020; Sanchez-Barrioluengo, Uyarra, Kitagawa, 2019; Thomas \& Pugh, 2020; Ward, Hernandez-Sanchez, \& Sanchez-Garcia, 2019). The knowledge economy is a factor in the adaptation of universities around the world (Dabic, 2021). The country's economy will be driven by entrepreneurship, which universities need to adapt constantly, especially towards entrepreneurship universities (Audretsch, 2014; Bell, 2011; Feola, Parente, \& Cucino, 2020). Universities around the world must play a role not only in education and research, but also to become entrepreneurial universities that drive innovation for society and the country (Alves, Fischer, Schaeffer, \& Queiroz, 2018; Gibb, 2012; Kirby, Guerrero, \& Urbano, 2011; Pugh, Lamine, Jack, \& Hamilton, 2018; Yusoff, Khan, Mubeen, \& Azam, 2013). Universities are the source of knowledge production, innovation, human capital development, and the generation of modern ideas such as entrepreneurial thinking (PadillaMelendez, Aguila-Obra, Lockett, \& Fuster, 2020). However, different universities in different areas will have different opportunities and expectations from society (Sanchez-Barrioluengo, Uyarra, Kitagawa, 2019). The definition of an entrepreneurial university is related to culture, mission, and knowledge management to develop innovations (Etzkowitz, et al., 2019). An entrepreneurial university must create a new body of knowledge and transfer that knowledge to society and the country (Audretsch, 2014). Because an entrepreneurial university is a machine or power to create innovation for society (Bell, 2011). An entrepreneurial university has the nature of being exposed to 
the outside in order to bring in the innovation process within the organization. It creates an image of open innovation that arises from collaborations with external organizations (Dabic, 2021). The nature of an entrepreneurial university is not only creating knowledge from research, but being an entrepreneurial university must bring social problems to study and present solutions to various social problems (Audretsch, 2014; Liu \& van der Sijde, 2021). The characteristics of an entrepreneurial university include having a clear strategy and design of a reasonable structure, corporate governance, social value creation, knowledge organization, innovation focus, and having the incubation center for entrepreneurs, engagement with other sectors of society, stakeholder participation, and internationalization (Gibb, 2012; Guerrero \& Urbano, 2010; Lehmann, Meoli, Paleari, \& Stockinger, 2020). An entrepreneurial university that drives an entrepreneurial society requires leadership in the creation of entrepreneurial thought, action, supportive institutions, and entrepreneurial capital (Audretsch, 2014). The core of an entrepreneurial university is the application of research knowledge to the economic system, which is the economic development of an entrepreneurial university (Feola, Parente, \& Cucino, 2020). The knowledge from the entrepreneurial universities that lead to society will also generate income and economic growth of society (Audretsch, 2014). One of the cornerstones of becoming an entrepreneurial university is technology transfer, which is related to knowledge creation and entrepreneurship in society (Feola, Parente, \& Cucino, 2020). Entrepreneurial universities must support the creation and transfer of technology as well as the creation of new entrepreneurs with a good knowledge base. In addition, the university must create personnel who behaves in accordance with the future entrepreneurial society (Audretsch, 2014; Lehmann, Meoli, Paleari, \& Stockinger, 2020). In terms of measuring the success of an entrepreneurial university, it was found to measure the number of new entrepreneurs or start-ups, income generation, job creation, and the Infrastructure Index (Kirby, Guerrero, \& Urbano, 2011). The study of Gibb (2012) indicates that every university is an entrepreneurial university at some level, but the challenge is to develop a university into a fully or systematically entrepreneurial university. The study of Elia, Secundo, and Passiante (2017) pointed out that the components of the development of an entrepreneurial university must include education, innovation, and network collaboration. In addition, the study of Sperrer, Muller, and Soos (2016) indicated that the principle of an entrepreneurial university was a key to success during unusual or unpredictable times.

\subsection{Development Factors}

\subsubsection{Strategy}

The mission and strategy of the university are important and have an impact on successfully building the university into an entrepreneurial university (Guerrero, Toledano, \& Urbano, 2ol1; Liu \& van der Sijde, 2021). Universities must formulate a strategy to create an organization with entrepreneurial characteristics to lead to an entrepreneurial university (Alves, Fischer, Schaeffer, \& Queiroz, 2018). The university must have a strategy to build cooperation with other organizations to develop entrepreneurship and innovation, which is a key factor in moving towards an entrepreneurial university (Dabic, 2021). The establishment of an entrepreneurial university strategy must be based on entrepreneurial principles, which will lead to further organizational structure design (Gibb, 2012). The university's strategy in terms of research focus and research quality are factors that affect the development of an entrepreneurial university (Alves, Fischer, Schaeffer, \& Queiroz, 2018). The transformation of oneself to an entrepreneurial university is thus aiming to develop innovation for society (Kirby, Guerrero, \& Urbano, 2011).

\subsubsection{Structure}

Having a structure that supports teaching and learning in the university to create innovators is a factor that affects the development of an entrepreneurial university (Alves, Fischer, Schaeffer, \& 
Queiroz, 2018). The structure of the university is important for entrepreneurship, such as research and development departments, innovation departments, the financial support departments. These are the structures of the university that will affect how it will be an entrepreneurial university in the future (Guerrero, Toledano, \& Urbano, 2011). Universities must have a structure to develop students to create innovation, which is a component of the development of an entrepreneurial university (Alves, Fischer, Schaeffer, \& Queiroz, 2018). Organizational design is an important part of the development of an entrepreneurial university by defining a structure that is flexible for decisionmaking, self-reliance, and accountability among the various departments within the university (Gibb, 2012). Therefore, the flexible structure of the university affects becoming an entrepreneurial university (Kirby, Guerrero, \& Urbano, 2011; Liu \& van der Sijde, 2021).

\subsubsection{System}

A study by Guerrero, Toledano, and Urbano (2011) who studied a case study in Spain on entrepreneurial universities found that both formal and informal mechanization influenced an entrepreneurial university. The university must have an incubation system for students to develop themselves into entrepreneurs, which is one of the functions of an entrepreneurial university (Alves, Fischer, Schaeffer, \& Queiroz, 2018). Having the process of creating innovation together with other organizations is essential for the university's development to become an entrepreneurial university in the future (Dabic, 2021). Academic programs at universities are a key tool in building students' entrepreneurial abilities (Alves, Fischer, Schaeffer, \& Queiroz, 2018). The university education program system plays a role in building a university into an entrepreneurial university (Guerrero, Toledano, \& Urbano, 2011). Therefore, the university system plays an important role in the development of the university to become an entrepreneurial university in the future.

\subsubsection{Competencies}

Creating a good model in a university that is suitable for learning results in the creation of a university to an entrepreneurial university (Guerrero, Toledano, \& Urbano, 2011). The competence of the university is related to the development of the citizens of the country that will result in more entrepreneurs. This has developed the university into an entrepreneurial university (Alves, Fischer, Schaeffer, \& Queiroz, 2018). The availability of different resources between universities affects an entrepreneurial university, with resources being a factor supporting the university's competence (Sanchez-Barrioluengo, Uyarra, Kitagawa, 2019). In addition, entrepreneurial leadership is one of the key factors contributing to the development of an entrepreneurial university as a mechanism that supports innovation and entrepreneurship in the university (Guerrero, Toledano, \& Urbano, 2011).

\subsubsection{Administrative pattern}

Good administration of the university, especially in the aspect of university governance, has an effect on building the university into an efficient entrepreneurial university (Guerrero, Toledano, \& Urbano, 2011; Liu \& van der Sijde, 2021). Building a network of entrepreneurs is considered a useful management aspect for the university's development to become an entrepreneurial university (Alves, Fischer, Schaeffer, \& Queiroz, 2018). In addition, the organization of meetings and seminars of the university also affects the aim of becoming an entrepreneurial university (Kirby, Guerrero, \& Urbano, 2011). Management styles and mechanisms that support innovation and entrepreneurship in universities from entrepreneurial leaders are very important factors affecting the development of an entrepreneurial university (Guerrero, Toledano, \& Urbano, 2011; Liu \& van der Sijde, 2021). However, the adaptation to an entrepreneurial university requires adjustment in entrepreneurship at all levels in the university (Kirby, Guerrero, \& Urbano, 2011). 


\subsubsection{Shared value}

Creating shared values in the development of an entrepreneurial university from the university's leaders has an effect on becoming an entrepreneurial university in the future (Guerrero, Toledano, \& Urbano, 2011). Being an entrepreneurial university requires the creation of shared values or entrepreneurial culture in the institution (Alves, Fischer, Schaeffer, \& Queiroz, 2018). Creating a culture that supports entrepreneurship and innovation is essential to becoming entrepreneurial universities (Thomas \& Pugh, 2020). Universities need to communicate, build partnerships, and take initiatives to develop entrepreneurial behavior in organizations to become an entrepreneurial university (Alves, Fischer, Schaeffer, \& Queiroz, 2018). Consequently, the university's support for entrepreneurship-related awards contributes to its striving towards becoming an entrepreneurial university (Kirby, Guerrero, \& Urbano, 2011).

\subsubsection{Personnel}

Human capital development is an important factor in an entrepreneurial economy (Elia, Secundo, \& Passiante, 2017). A study by Guerrero, Toledano, and Urbano (2011) who studied a case study in Spain on entrepreneurial universities found that personnel factors affect the development of an entrepreneurial university in case study in Spain. The ability of an institution, especially to conduct quality research, demonstrates the entrepreneurial ability of the university (Alves, Fischer, Schaeffer, \& Queiroz, 2018). Creating an entrepreneurial attitude of university personnel will ultimately affect the university's formation into an entrepreneurial university (Elia, Secundo, \& Passiante, 2017; Guerrero, Toledano, \& Urbano, 2011; Kirby, Guerrero, \& Urbano, 2011). Therefore, the competence of university personnel that affects innovation development is a factor that affects the development of an entrepreneurial university (Alves, Fischer, Schaeffer, \& Queiroz, 2018).

\subsubsection{Politics and policies}

The policy of building an entrepreneurial university is a challenge to the university's development to create students with entrepreneurial character (Alves, Fischer, Schaeffer, \& Queiroz, 2018; Elia, Secundo, \& Passiante, 2017). The policy of the university administrators is important for becoming an entrepreneurial university in the future (Guerrero, Toledano, \& Urbano, 2011). A policy that supports the entrepreneurial concept to encourage university personnel to conduct research to create a body of knowledge and innovation is one of the factors that affect the entrepreneurial university (Feola, Parente, \& Cucino, 2020). Policies and processes that support teaching and learning in the university to create students with entrepreneurial characteristics are factors that affect the development of an entrepreneurial university (Alves, Fischer, Schaeffer, \& Queiroz, 2018). Exposure to the outside to lead in the process of creating innovation within the organization or collaborating with external organizations is an important factor in moving towards an entrepreneurial university (Dabic, 2021; Dalmarco, Hulsink, \& Blois, 2018; Pugh, Lamine, Jack, \& Hamilton, 2018).

\subsubsection{Economics}

Entrepreneurship-related activities are the building blocks of the economy to create opportunities for innovation and commercialization (Alves, Fischer, Schaeffer, \& Queiroz, 2018). Economic environmental factors affect the path towards becoming an entrepreneurial university; this economic factor will ultimately determine the way to develop into an entrepreneurial university (Kirby, Guerrero, \& Urbano, 2011). The study of Elia, Secundo, and Passiante (2017) indicated that the development of an entrepreneurial university is clearly linked to economic development and growth, often related to innovation and entrepreneurship. 


\subsubsection{Society}

Social capital arises from the relationship of people in society and is an important factor in the development of an entrepreneurial organization (Padilla-Melendez, Aguila-Obra, Lockett, \& Fuster, 2020). Entrepreneurship-related activities are a social phenomenon due to the changing social pressures around the world (Alves, Fischer, Schaeffer, \& Queiroz, 2018). Social impact is one of the roles of the university, especially in being an entrepreneurial university (Thomas \& Pugh, 2020). Different types of universities in different areas have different social expectations (SanchezBarrioluengo, Uyarra, Kitagawa, 2019). Universities must be an agency that has to give back to the social sector in terms of knowledge development, research, innovation, and economic benefits (Thomas \& Pugh, 2020). Having entrepreneurial capital focused on local institutions is one of the key elements in becoming an entrepreneurial university (Alves, Fischer, Schaeffer, \& Queiroz, 2018).

\subsubsection{Technologies}

The technological structure adopted by universities for organizational development such as technology in innovation and research development of the university affects the development of an entrepreneurial university (Guerrero, Toledano, \& Urbano, 2011). It was found that entrepreneurial universities will use technological advances to create activities in the university system and structure to lead to the development of an entrepreneurial university (Alves, Fischer, Schaeffer, \& Queiroz, 2018). Technology transfer related to knowledge creation and entrepreneurship is one of the factors of being an entrepreneurial university (Feola, Parente, \& Cucino, 2020; Liu \& van der Sijde, 2021). Therefore, the university's support in technology transfer affects its aim to become an entrepreneurial university (Kirby, Guerrero, \& Urbano, 2011).

\subsubsection{Regulation and law}

Changes in law and regulation at both the national and university level have influenced the development of entrepreneurial activities (Alves, Fischer, Schaeffer, \& Queiroz, 2018). Changes in the education system affect the shift towards becoming an entrepreneurial university because it inevitably affects the administration of the university (Kirby, Guerrero, \& Urbano, 2011). The determination of various measures and governmental organizations has also influenced the development of an entrepreneurial university (Guerrero, Urbano, \& Salamzadeh, 2014). Therefore, it is undeniable that government administration in each country affects the transformation of domestic universities into entrepreneurial universities.

\subsubsection{Environment}

Changes in the external environment are the impetus for universities to adapt to the changes of the world where universities have to adapt to entrepreneurial universities (Liu \& van der Sijde, 2021). Universities around the world need to adapt to support the growth of the $21^{\text {st }}$ century. It is imperative to develop universities in the right format to create competent citizens in line with this century, especially in the direction of an entrepreneurial university (Alves, Fischer, Schaeffer, \& Queiroz, 2018). The university environment is essential to the development of entrepreneurial attributes, whether it is the facilities or technology that the university provides for high-performing education (Alves, Fischer, Schaeffer, \& Queiroz, 2018; Feola, Parente, \& Cucino, 2020). The university's focus on research and information management in the teaching and learning process is essential to the development of an entrepreneurial university (Alves, Fischer, Schaeffer, \& Queiroz, 2018). Adaptation to an entrepreneurial university is an adaptation to adapt to changes in the external environment of the organization (Kirby, Guerrero, \& Urbano, 2011). Environmental awareness also affects the university's development into an entrepreneurial university in the future (Alves, Fischer, Schaeffer, \& Queiroz, 2018). 


\section{Research Framework}

The conceptual framework of this research was based on the literature review and related research, resulting in the conceptual framework as shown in Figure 1.

\begin{tabular}{|c|c|}
\hline $\begin{array}{l}\text { Development Factors } \\
\text { 1. Organizational strategy } \\
\text { 2. Organizational structure } \\
\text { 3. System } \\
\text { 4. Competencies } \\
\text { 5. Administrative pattern } \\
\text { 6. Shared value } \\
\text { 7. Personnel } \\
\text { 8. Politics and policies } \\
\text { 9. Economics } \\
\text { 10. Society and culture } \\
\text { 11. Technologies } \\
\text { 12. Regulation and law } \\
\text { 13. Environment }\end{array}$ & $\begin{array}{l}\text { Characteristics of an } \\
\text { Entrepreneurial University } \\
\text { 1. Administration } \\
\text { 2. Capability } \\
\text { 3. Entrepreneurial learning } \\
\text { 4. Entrepreneurial preparation } \\
\text { 5. Learning Networks } \\
\text { 6. International orientation } \\
\text { 7. Outcome measurement }\end{array}$ \\
\hline
\end{tabular}

Figure 1: Research framework

\section{Research Methodology}

\subsection{Population and Sample}

The population of this study is current personnel at Rajabhat Universities across Thailand. With a total population of 4,847 people, the researchers calculated the sample size of the known population formula with the Cochran (1977) formula. According to Cochran's sampling technique at the confidence level and error of $95 \%$ and $5 \%$, respectively, the sample size was 356 .

\subsection{Research Tool and data collection}

This study used questionnaires as a tool to collect data from the given samples. The researcher collected data from 360 participants. All questionnaires have been checked for accuracy and are complete. The first part of the questionnaire deals with demographic data, while the second part deals with the key variables of the research conceptual framework derived from the review of the relevant literature. To verify the validity of research tools, the researcher sent five experts to check the validity of the questionnaire. The researcher used the Item-objective congruence (IOC) index for the purpose of checking the validity of the questionnaire. As a result of the test, it was found that all questions had an index value of more than o.6, so the research questionnaire passed the validity test. For the questionnaire reliability test, the researcher used the Cronbach's Alpha statistics in this test. The results showed that the questionnaire passed the reliability test at a test value above 0.7 as shown in Table 1 (Hair, Black, Babin, \& Anderson, 2014). In the process of collecting data from the questionnaire, the researcher used a stratified random sampling method. In the stratified data collection of the study population, the researchers defined the size as small, medium, and large. 
Table 1: Research questionnaire details

\begin{tabular}{|l|l|l|c|}
\hline Constructs & Variables (Number of Items) & sources & $\begin{array}{c}\text { Cronbach's } \\
\text { Alpha }\end{array}$ \\
\hline \multirow{2}{*}{$\begin{array}{l}\text { Development } \\
\text { factors }\end{array}$} & $\begin{array}{l}\text { Organizational strategy, Organizational } \\
\text { structure, System, Competencies, } \\
\text { Administrative patterns, Shared value, } \\
\text { Personnel, Politics and policies, Economics, } \\
\text { Society and culture, Technologies, Regulation } \\
\text { and law, and Environment (Total 65 Items) }\end{array}$ & $\begin{array}{l}\text { Alves, Fischer, Schaeffer, and } \\
\text { Queiroz, (2018); Feola, Parente, } \\
\text { and Cucino (2020); Gibb (2012); } \\
\text { Guerrero, Toledano, and } \\
\text { Urbano (2011); Kirby, Guerrero, } \\
\text { and Urbano (2011) }\end{array}$ & 0.986 \\
\hline $\begin{array}{l}\text { Entrepreneurial } \\
\text { University }\end{array}$ & $\begin{array}{l}\text { Administration, Capability, Entrepreneurial } \\
\text { learning, Entrepreneurial preparation, Learning } \\
\text { networks, International orientation, and } \\
\text { Outcome measurement (Total 49 Items) }\end{array}$ & $\begin{array}{l}\text { Elia, Secundo, and Passiante } \\
\text { (2017) }\end{array}$ & 0.986 \\
\hline
\end{tabular}

\subsection{Research Statistics and evaluation}

The research used two parts of statistical analysis: descriptive statistics and inferential statistics. Descriptive statistical analysis used frequency, percentage, mean, and standard deviation. In the field of inferential statistical analysis, the researcher used correlation analysis and stepwise multiple regression analyses.

Table 2: The evaluation criteria of the variable means

\begin{tabular}{|l|l|}
\hline Means & Evaluation criteria \\
\hline $4.21-5.00$ & Highest level \\
$3.41-4.20$ & High level \\
$2.61-3.40$ & Moderate level \\
$1.81-2.60$ & Low level \\
$1.00-1.80$ & Lowest level \\
\hline
\end{tabular}

Evaluating the mean of the research variables, the researcher used the evaluation criteria as shown in Table 2. The assessment will start from the lowest level to the highest level.

\section{Research Results}

The results of the descriptive statistical analysis are shown in Table 3-5, the results of the inferential statistical analysis are shown in Table 6-9. The sample size used in the statistical analysis was 360.

Table 3: Descriptive statistics of research respondents

\begin{tabular}{|c|c|c|}
\hline Variables & Frequencies & $\%$ \\
\hline \multicolumn{3}{|l|}{ Gender } \\
\hline Male & 128 & 35.6 \\
\hline Female & 232 & 64.4 \\
\hline \multicolumn{3}{|l|}{ Age } \\
\hline$<30$ years & 12 & $3 \cdot 3$ \\
\hline 30-35 years & 68 & 18.9 \\
\hline 36-40 years & 119 & 33.1 \\
\hline$>40$ years & 161 & 44.7 \\
\hline \multicolumn{3}{|l|}{ Education } \\
\hline Bachelor Degree or below & 84 & 23.3 \\
\hline Master Degree & 172 & 47.8 \\
\hline Doctor Degree & 104 & 28.9 \\
\hline
\end{tabular}




\begin{tabular}{|l|c|c|}
\hline Variables & \multicolumn{2}{|c|}{ Frequencies } \\
\hline Positions & \multicolumn{2}{|c|}{$\%$} \\
\hline Administrator level & 49 & 13.6 \\
\hline Director level & 42 & 11.7 \\
\hline Academic staff & 129 & 35.8 \\
\hline Supportive staff & 140 & 38.9 \\
\hline Work experience in University (years) & \multicolumn{2}{|c|}{8.6} \\
\hline 4 or fewer & 31 & 35.0 \\
\hline 5 -10 & 126 & 29.7 \\
\hline $11-14$ & 107 & 26.7 \\
\hline 15 or more & 96 & \\
\hline
\end{tabular}

Most of the respondents were female (232, 64.4\%), over forty years old (161, 44.7\%), had a master's degree $(172,47.8 \%)$, held a support staff position (140, 38.9\%), and had five to ten years of work experience $(126,35.0 \%)$.

Table 4: Descriptive statistics of the development factors

\begin{tabular}{|l|c|c|l|}
\hline Variables & Means & Standard Deviation & Evaluation \\
\hline Organizational strategy & 3.80 & 0.87 & High level \\
\hline Organizational structure & 3.85 & 0.82 & High level \\
\hline System & 3.76 & 1.13 & High level \\
\hline Competencies & 3.98 & 0.80 & High level \\
\hline Administrative pattern & 3.86 & 0.84 & High level \\
\hline Shared value & 3.76 & 0.83 & High level \\
\hline Personnel & 3.96 & 0.97 & High level \\
\hline Politics and policies & 3.84 & 0.74 & High level \\
\hline Economics & 4.09 & 0.70 & High level \\
\hline Society and culture & 4.17 & 0.65 & High level \\
\hline Technologies & 4.20 & 0.66 & High level \\
\hline Regulation and law & 3.93 & 0.71 & High level \\
\hline Environment & 4.11 & 0.62 & High level \\
\hline Overall development factors & 3.95 & $\mathbf{o . 8 0}$ & High level \\
\hline
\end{tabular}

The results of the descriptive statistical analysis of the thirteen factors of organizational development revealed that the opinion of Rajabhat University personnel in overall development factors was high and when separating each factor, it was found that the opinions of personnel in all factors of development were high as shown in Table 4. When considering the distribution of the data from the standard deviation and the mean, it was found that the information was well distributed.

Table 5: Descriptive statistics of the characteristics of an entrepreneurial university

\begin{tabular}{|l|c|c|l|}
\hline Variables & Means & Standard Deviation & Evaluation \\
\hline Administration & 3.83 & 0.73 & High level \\
\hline Capability & 3.69 & 0.85 & High level \\
\hline Entrepreneurial learning & 3.89 & 0.73 & High level \\
\hline Entrepreneurial preparation & 3.77 & 0.69 & High level \\
\hline Learning Networks & 3.85 & 0.73 & High level \\
\hline International orientation & 3.51 & 0.88 & High level \\
\hline Outcome measurement & 3.56 & 0.91 & High level \\
\hline Characteristics of an entrepreneurial university & 3.73 & $\mathbf{0 . 6 9}$ & High level \\
\hline
\end{tabular}

Table 5 shows the results of descriptive statistical analysis of the characteristics of an entrepreneurial 
university, it was found that the average opinions of personnel of Thai Rajabhat University regarding entrepreneurial university were high, both overall and in every aspect. When examining the distribution of the data from the standard deviation and the mean, it was found that the information on the characteristics of the entrepreneurial university was also well distributed.

Table 6: Correlation matrix of key variables in development factors

\begin{tabular}{|c|c|c|c|c|c|c|c|c|c|c|c|c|}
\hline Variables & $\mathbf{X} \mathbf{1}$ & $\mathbf{X}_{2}$ & $\mathrm{X}_{3}$ & $X_{4}$ & $\mathrm{X}_{5}$ & $\mathrm{X6}$ & $\mathrm{X}_{7}$ & $\mathrm{X8}$ & $\mathbf{X 9}_{9}$ & X1o & $\mathbf{X 1 1}$ & $\mathrm{X} 12$ \\
\hline Strategy $\left(\mathrm{X}_{\mathbf{1}}\right)$ & 1 & & & & & & & & & & & \\
\hline Structure $\left(\mathrm{X}_{2}\right)$ & $.793^{*}$ & 1 & & & & & & & & & & \\
\hline System $\left(\mathrm{X}_{3}\right)$ & $.637^{* * 4}$ & $.660^{\text {*** }}$ & 1 & & & & & & & & & \\
\hline Competencies $\left(\mathrm{X}_{4}\right)$ & $.650^{*}$ & $.705^{*}$ & $.577^{*}$ & 1 & & & & & & & & \\
\hline Pattern $\left(\mathrm{X}_{5}\right)$ & .710 & .753 & .637 & $.708^{* * 1}$ & 1 & & & & & & & \\
\hline Shared value (X6) & $.704^{*}$ & $.712^{*}$ & $.648^{* *}$ & $.666^{\text {** }}$ & $.802^{* * x}$ & 1 & & & & & & \\
\hline Personnel $\left(\mathrm{X}_{7}\right)$ & $.557^{*}$ & $.625^{*}$ & $.518^{* x}$ & .582 & $.662^{* * 4}$ & $.654^{* *}$ & 1 & & & & & \\
\hline Politics (X8) & $.656^{*}$ & .651 & $.566^{* *}$ & $.607^{* *}$ & $643^{* *}$ & .617 & $.527^{* *}$ & 1 & & & & \\
\hline Economics (X9) & .400 & $.431^{*}$ & $.355^{*}$ & $.465^{* *}$ & $.471^{* *}$ & $.473^{*}$ & $.440^{* * 1}$ & .525 & 1 & & & \\
\hline Society (X10) & $.378^{*}$ & $.385^{*}$ & $.314^{*}$ & $.465^{* * *}$ & .399 & $.401^{*}$ & $.419^{* * \pi}$ & $.471^{*}$ & $.617^{* * x}$ & 1 & & \\
\hline Technology (X11) & $.406^{\pi}$ & .430 & .334 & .439 & .401 & $.45^{2 *}$ & .406 & $.498^{* 7 *}$ & $.688^{\prime \prime}$ & $.738^{* *}$ & 1 & \\
\hline Regulation (X12) & .539 & $.566^{* *}$ & .429 & $.513^{* * *}$ & $.510^{* * *}$ & $.498^{* *}$ & $.443^{* * x}$ & $.678^{* *}$ & $.531^{* * *}$ & $.606^{* *}$ & $.618^{* *}$ & 1 \\
\hline Environment (X13) & $.398^{* *}$ & $.438^{* *}$ & $.365^{* 1}$ & $.535^{* * 1}$ & $.493^{* * 4}$ & $.442^{* * *}$ & $.424^{* *}$ & $.550^{* * *}$ & $.55^{* *}$ & $.666^{* *}$ & .622 & $.600^{* *}$ \\
\hline
\end{tabular}

Note: ${ }^{* *}$ it is significant at the .01 level

The results of the correlation analysis of the development factor sub-variables are shown in Table 6 . When considering the correlation analysis results from the use of Hair, et al. (2014)'s criterion that assigns a high correlation level with a correlation coefficient exceeding 0.7 , it was found that most of the variable pairs had a significant moderate correlation. Only eight pairs of sub-variables in the development factor with high correlation were found included strategy and structure, strategy and pattern, strategy and shared value, structure and pattern, structure and shared value, competencies and pattern, pattern and shared value, and society and technology.

Table 7: Correlation matrix of key variables in characteristics of an entrepreneurial university

\begin{tabular}{|c|c|c|c|c|c|c|c|}
\hline Variables & Y1 & $\mathbf{Y}_{2}$ & $\mathrm{Y}_{3}$ & $\mathrm{Y}_{4}$ & $\mathrm{Y}_{5}$ & Y6 & $\mathrm{Y}_{7}$ \\
\hline Administration (Y1) & 1 & & & & & & \\
\hline Capability (Y2) & $.782 * *$ & 1 & & & & & \\
\hline Entrepreneurial learning $\left(\mathrm{Y}_{3}\right)$ & $.724 * *$ & $.735^{* *}$ & 1 & & & & \\
\hline Entrepreneurial preparation $\left(\mathrm{Y}_{4}\right)$ & $.748 * *$ & $.753 * *$ & $.784 * *$ & 1 & & & \\
\hline Networks (Y5) & $.734 * *$ & $.745^{* *}$ & $.725 * *$ & $.804 * *$ & 1 & & \\
\hline International orientation (Y6) & $.665 * *$ & $.713 * *$ & $.620 * *$ & $.733 * *$ & $.745 * *$ & 1 & \\
\hline Outcome measurement $\left(\mathrm{Y}_{7}\right)$ & $.711^{* *}$ & $.733 * *$ & $.638 * *$ & $.710 * *$ & $.714 * *$ & $.828 * *$ & 1 \\
\hline
\end{tabular}

Note: ${ }^{* *}$ it is significant at the .or level.

Table 7 shows the results of the correlation analysis of the factorial characteristics of the entrepreneurial university. Correlation analysis of seven sub-variable pairs of entrepreneurial university characteristics revealed that most of the sub-variable pairs were highly correlated except three with moderate correlation included administrative and international orientation, entrepreneurial learning and international orientation, and entrepreneurial learning and outcome measurement. 
Table 8: Regression result of factors affecting characteristics of an entrepreneurial university

\begin{tabular}{|c|c|c|c|c|c|}
\hline Variables & \begin{tabular}{|c|} 
Unstandardized Coefficients \\
$\beta$
\end{tabular} & \begin{tabular}{|c|} 
Standardized Coefficients \\
beta \\
\end{tabular} & t-statistics & Sig. & VIF \\
\hline Constant & 0.525 & & 3.983 & $0.000^{*}$ & \\
\hline Organizational strategy & 0.287 & 0.360 & 7.749 & $0.000^{*}$ & 3.253 \\
\hline Organizational structure & 0.111 & 0.131 & 2.777 & $0.006^{*}$ & 2.405 \\
\hline System & 0.093 & 0.153 & 4.121 & $0.000^{*}$ & 2.082 \\
\hline Shared value & 0.137 & 0.164 & 3.927 & $0.000^{*}$ & 2.634 \\
\hline Politics and policies & 0.174 & 0.185 & 4.623 & $0.000^{*}$ & 1.681 \\
\hline Economics & -0.103 & -0.104 & -3.136 & $0.002^{*}$ & 1.657 \\
\hline Environment & 0.139 & 0.124 & 3.708 & $0.000^{*}$ & $3 \cdot 378$ \\
\hline $\mathrm{F}$ & 165.284 & & & & \\
\hline Sig. of F & $0.000^{*}$ & & & & \\
\hline $\mathrm{R}^{2}$ & 0.767 & & & & \\
\hline Adjusted $\mathrm{R}^{2}$ & 0.762 & & & & \\
\hline
\end{tabular}

Note: * it is significant at the .05 level.

The results of the stepwise multiple regression analyses of the overall entrepreneurial university attributes are shown in Table 8. From the analysis of the influence of various development factors on the characteristics factors of the overall entrepreneurial university, it found that there were seven factors of development that had a significant impact on the overall picture of an entrepreneurial university: organizational strategy, organizational structure, system, shared value, politics and policies, economics, and environment. These seven factors account for 76.7 percent of the dependent variable, which is the overall picture of an entrepreneurial university. The standardized regression equation of the overall entrepreneurial university attributes can be shown as follows: Overall entrepreneurial university $=0.360$ Organizational_strategy +0.131 Organizational_structure + 0.153 System + 0.164Shared_value + 0.185Politics_and_policies - 0.104Economics + 0.124Environment

Table 9: Regression results of factors affecting each aspect of an entrepreneurial university

\begin{tabular}{|l|c|c|c|c|c|c|c|}
\hline \multirow{2}{*}{ Development factors } & \multicolumn{7}{|c|}{ Characteristics of an entrepreneurial university } \\
\cline { 2 - 9 } & Administration & Capability & Learning & Preparation & Networks & International & Outcome \\
\hline Strategy & $\mathrm{X}$ & $\mathrm{X}$ & $\mathrm{X}$ & $\mathrm{X}$ & $\mathrm{X}$ & $\mathrm{X}$ & $\mathrm{X}$ \\
\hline Structure & $\mathrm{X}$ & & $\mathrm{X}$ & & $\mathrm{X}$ & & $\mathrm{X}$ \\
\hline System & $\mathrm{X}$ & $\mathrm{X}$ & & $\mathrm{X}$ & $\mathrm{X}$ & $\mathrm{X}$ & $\mathrm{X}$ \\
\hline Competencies & & & & & & & \\
\hline Administrative pattern & & & & $\mathrm{X}$ & & & \\
\hline Shared value & $\mathrm{X}$ & $\mathrm{X}$ & $\mathrm{X}$ & & $\mathrm{X}$ & $\mathrm{X}$ & $\mathrm{X}$ \\
\hline Personnel & & & & & & & \\
\hline Politics and policies & $\mathrm{X}$ & & $\mathrm{X}$ & $\mathrm{X}$ & $\mathrm{X}$ & $\mathrm{X}$ & $\mathrm{X}$ \\
\hline Economics & & $\mathrm{X}$ & & & $\mathrm{X}$ & & \\
\hline Society & & & $\mathrm{X}$ & & & & \\
\hline Technologies & & & & & & $\mathrm{X}$ & $\mathrm{X}$ \\
\hline Regulation and law & & $\mathrm{X}$ & & & & $\mathrm{X}$ & $\mathrm{X}$ \\
\hline Environment & & $\mathrm{X}$ & & $\mathrm{X}$ & $\mathrm{X}$ & $\mathrm{X}$ & \\
\hline R square (\%) & 58.9 & 60.9 & 53.6 & 63.1 & 59.2 & 60.6 & 62.5 \\
\hline $\mathrm{F}$ & 101.5 & 91.65 & 81.62 & 121.02 & 73.08 & 77.22 & 83.84 \\
\hline sig of F & $<.001$ & $<.001$ & $<.001$ & $<.001$ & $<.001$ & $<.001$ & $<.001$ \\
\hline
\end{tabular}

Table 9 shows the results of the multiple regression analyses of various development factors affecting the entrepreneurial university characteristics in each aspect. There are seven characteristics of an entrepreneurial university: administrative, capability, learning, preparation, networks, international, 
and outcome. The results of statistical analysis revealed that most of the variables of development factors significantly affected all seven aspects of entrepreneurial university characteristics except two that had no effect: and competencies and personnel. And considering the most common number of developmental variables affecting the seven aspects of entrepreneurial university characteristics, the results of the analysis revealed that the most influential aspect was organizational strategy, which affects all aspects of an entrepreneurial university, followed by the system, shared value, politics and policies, organizational structure, and the environment, respectively.

\section{Summary and Discussion}

This research aims to study the development of Thai universities that originally focused on the quality of education, leading to the development of an entrepreneurial university, especially the Rajabhat University of Thailand. The researcher is interested in various factors related to the development of an entrepreneurial university of Rajabhat University in Thailand included organizational strategy, organizational structure, system, competencies, administrative patterns, shared value, personnel, politics and policies, economics, society and culture, technologies, regulation and law, and environment. While the entrepreneurial university variable consists of a total of seven study factors: administration, capability, entrepreneurial learning, entrepreneurial preparation, learning networks, international orientation, and outcome measurement. The preliminary findings showed that the thirteen development variables were significantly correlated at moderate to high levels, and most of the correlations of the seven entrepreneurial university variables were at a high level. In terms of opinions of Rajabhat University personnel who are participants in this research, opinions on various aspects of development and characteristics of Rajabhat University's entrepreneurial universities are at a high level. The findings of this research show that the current Rajabhat University's development has a direction towards becoming an entrepreneurial university in the future. However, when considering the influence of each factor of development on the characteristics of an entrepreneurial university, the study found that there were seven development factors that had a significant impact on the entrepreneurial hierarchy: organizational strategy, organizational structure, system, shared value, politics and policies, economics, and environment. In addition, when analyzing the characteristics of entrepreneurial universities, the results revealed that the development factors that most affect the characteristics of entrepreneurial universities are as follows: organizational strategy, system, shared value, politics and policies, organizational structure, and environment. These results were consistent with previous studies including the study of Liu and van der Sijde (2021), Dabic (2021), and Alves, Fischer, Schaeffer, and Queiroz (2018) who found that the strategy of the university affects the presence of entrepreneurial attributes such as research strategy and innovation development strategy, which ultimately leads to becoming an entrepreneurial university, the study by Gibb (2012), Kirby, Guerrero, and Urbano (2011), and Alves, Fischer, Schaeffer, and Queiroz (2018) found that appropriate organizational structures such as learning support structures, flexible administrative structures, these structures contributed towards becoming an entrepreneurial university, the study of Dabic (2021), Guerrero, Toledano, and Urbano (2011), and Alves, Fischer, Schaeffer, and Queiroz (2018) found that a good enough university system, such as an entrepreneurial incubator in an organization, a system that supports innovation capacity, can create an entrepreneurial university, the study by Thomas and Pugh (2020), Guerrero, Toledano, and Urbano (2011), and Kirby, Guerrero, and Urbano (2011) found that the shared values the organization creates as a guide or organizational culture for university personnel contributes to the development of an entrepreneurial university, the study of Feola, Parente, and Cucino (2020), Elia, Secundo, and Passiante (2017), Dalmarco, Hulsink, and Blois (2018), and Pugh, Lamine, Jack, and Hamilton (2018) found that politics and policy-making in building a university into an entrepreneurial university affect the work-oriented management of personnel and the right direction towards becoming an entrepreneurial university successfully, and the study of Liu and van der Sijde (2021), Feola, Parente, and Cucino (2020), Kirby, Guerrero, and Urbano (2011), and Alves, Fischer, 
Schaeffer, and Queiroz (2018) found that the environment is constantly changing and universities that want to be entrepreneurial universities need to adapt to the changing external environment by being prepared for changes and making the ability to adapt to changes in the environment is essential to becoming an entrepreneurial university.

\section{Recommendation}

Because this research aims to study the development factors that affect the entrepreneurial university. Therefore, recommendations will be an important development factor based on research findings. The research findings summarize the key factors influencing an entrepreneurial university, which are organizational strategy, organizational structure, system, shared value, politics and policies, economics, and environment. The administration of Thai Rajabhat University should pay attention and formulate a development plan that corresponds to these factors in developing Thai Rajabhat University to become an entrepreneurial university. Most of these factors are internal factors that the administration coming to Rajabhat University can plan, formulate policies, manage, lead, and control such plans in order to develop into an entrepreneurial university. Based on this research, executives can start by formulating organizational strategies and policies based on learning about changing environmental and economic factors, and then formulate management structures and systems. After that, it is to create shared values in the university by linking it to the creation of a corporate culture that leads to an entrepreneurial university. However, it took years to develop into an entrepreneurial university. This research is a one-time cross-sectional study. Therefore, in order for the development of an entrepreneurial university to become a reality, a future study should be made to assess the evaluation of these development factors and the success of their operations as an entrepreneurial university.

\section{References}

Alves, A. C., Fischer, B., Schaeffer, P. R., \& Queiroz, S. (2018). Determinants of student entrepreneurship: An assessment on higher education institutions in Brazil. Innovation E Management Review, 16(2), 96-117.

Audretsch, D. B. (2014). From the entrepreneurial university to the university for the entrepreneurial society. Journal of Technology Transfer, 39, 313-321.

Bell, J. R. (2011). Engines of innovation: The entrepreneurial university in the twenty-first century. New England Journal of Entrepreneurship, 14(2), 81-83.

Cardella, G. M., Hernandez-Sanchez, B. R., \& Sanchez-Garcia, J. C. (2019). Entrepreneurship and family role: A systematic review of a growing research. Frontiers in Psychology, 10, 1-17.

Cochran, W. G., 1977. Sampling techniques. 3rd ed. New York: John Willey and Sons.

Dabic, M. (2021). Entrepreneurial university in the European Union: EU in the EU. Journal of the Knowledge Economy, 12, 115-119.

Dalmarco, G., Hulsink, W., \& Blois, G. V. (2018). Creating entrepreneurial universities in an emerging economy: Evidence from Brazil. Technological Forecasting \& Social Change. Retrieved on $13^{\text {th }}$ April 2021 from https://www.researchgate.net/publication/324535654

Elia, G., Secundo, G., \& Passiante, G. (2017). Pathways towards the entrepreneurial university for creating entrepreneurial engineers: An Italian case. International journal of Entrepreneurship and Innovation Management, 21(1/2), 27-48.

Etzkowitz, H., Germain-Alamartine, E., Keel, J., Kumar, C., Kaden Smith, N., \& Albats, E. (2019). Entrepreneurial university dynamics: Structured ambivalence, relative deprivation and institution formulation in the Stanford innovation system. Technological Forecasting and Social Change, 141, 159-171.

Feola, R., Parente, R., \& Cucino, V. (2020). The entrepreneurial university: How to develop the entrepreneurial orientation of academia. Journal of the Knowledge Economy. Retrieved on $14^{\text {th }}$ May 2021 from https://link.springer.com/article/10.1007/s13132-020-00675-9

Fredin, S. \& Liden, A. (2020). Entrepreneurial ecosystems: towards a systemic approach to entrepreneurship? Geografisk Tidsskrift-Danish Journal of Geography, 120(2), 87-97.

Gibb, A. (2012). Exploring the synergistic potential in entrepreneurial university development: towards the building of a strategic framework. Annals of Innovation \& Entrepreneurship, 3(1), 1-21. 
Guerrero, M., Rialp, J., \& Urbano, D. (2008). The impact of desirability and feasibility on entrepreneurial intentions: A structural equation model. Retrieved on $7^{\text {th }}$ April 2021 from https://www.researchgate.net/publication/226710054

Guerrero, M., Toledano, N., \& Urbano, D. (2011). Entrepreneurial universities and support mechanisms: A Spanish case study. International journal of Entrepreneurship and Innovation Management, 13(2), 144-16o.

Guerrero, M. \& Urbano, D. (2010). The development of an entrepreneurial university. Journal of Technology Transfer. Retrieved on $7^{\text {th }}$ April 2021 from https://www.researchgate.net/publication/226634238

Guerrero, M., Urbano, D., \& Salamzadeh, A. (2014). Evolving entrepreneurial universities: Experiences and challenges in the Middle Eastern context. Retrieved on $5^{\text {th }}$ May 2021 from https://www.researchgate.net/publication/311773139

Hair, J. F., Black, W. C., Babin, B. J., \& Anderson, R. E., (2014). Multivaliate data analysis. $7^{\text {th }}$ ed. US: Pearson Education.

Kirby, D. A., Guerrero, M., \& Urbano, D. (2011). Making universities more entrepreneurial: Development of a model. Canadian Journal of Administrative Science, 28(3), 302-316.

Lassen, A. H. (2007). Corporate entrepreneurship: An empirical study of the importance of strategic considerations in the creation of radical innovation. Managing Global Transitions, 5(2), 109-131.

Lehmann, E. E., Meoli, M., Paleari, S., \& Stockinger, S. A. E. (2020). The role of higher education for the development of entrepreneurial ecosystems, European Journal of Higher Education, 10(1), 109.

Liu, S. \& van der Sijde, P. C. (2021). Towards the entrepreneurial university 2.o: reaffirming the responsibility of universities in the era of accountability. Sustainability, 13, 1-14.

Margaca, C., Hernandez-Sanchez, B., Sanchez-Garcia, J. C., \& Cardella, G. M. (2021). The role of psychological capital and gender in university students' entrepreneurial; intentions. Frontiers in Psychology, 11, 1-16.

Padilla-Melendez, A., Aguila-Obra, A. R. D., Lockett, N., \& Fuster, E. (2020). Entrepreneurial universities and sustainable development: The Network bricolage process of academic entrepreneurs. Sustainability, $12,1-17$.

Popowska, M. (2020). Corporate entrepreneurship: A literature review and future research perspectives. International Journal of Contemporary Management, 19(1), 61-87.

Pugh, R., Lamine, W., Jack, S., \& Hamilton, E. (2018). The entrepreneurial university and the region: What role for entrepreneurship departments? European Planning Studies, 26(9), 1835-1855.

Sakhdari, K. (2016). Corporate entrepreneurship: A review and future research agenda. Technology Innovation Management Review, 6(8), 5-18.

Sanchez-Barrioluengo, M. Uyarra, E., \& Kitagawa, F. (2019). Understanding the evolution of the entrepreneurial university: The case of English higher education institutions. High Education Quarterly, 73, 469-495.

Sperrer, M., Muller, C., \& Soos, J. (2016). The concept of the entrepreneurial university applied to universities of technology in Austria: Already reality or a vision of the future? Technology Innovation Management Review, 6(10), 37-53.

Thomas, E. \& Pugh, R. (2020). From 'entrepreneurial' to 'engaged' universities: Social innovation for regional development in the global south. Regional Studies, 54(12), 1631-1643.

Tseng, C. \& Tseng, C. C. (2019). Corporate entrepreneurship as a strategic approach for internal innovation performance. Asia Pacific Journal of Innovation and Entrepreneurship, 13(1), 108-120.

Ward, A., Hernandez-Sanchez, B. R., \& Sanchez-Garcia, J. C. (2019). Entrepreneurial potential and gender effects: The role of personality traits in university students' entrepreneurial intentions. Frontiers in Psychology, 10, 118.

Yusoff, R. M., Khan, F., Mubeen, A., \& Azam, K. (2013). A study about factors influencing the university performance. Jurnal Teknologi (Social Science), 64(2), 145-149. 